\title{
A REVIEW ABOUT BIOACTIVE COMPOUNDS OF FENUGREEK (Trigonella foenum-graceum)
}

\author{
Kousalya.N, Ishwarya.R, Logeshwaran.V, Sabarinath.K, Sandhiya.S, Arun.P \\ Department of Biotechnology, \\ Dr. N. G. P Arts and Science College, (autonomous) Coimbatore-48,
}

\begin{abstract}
Fenugreek (Trigonella foenum-graceum) is one of the mostly used medicinal herbs. Fenugreek seeds are rich in source of minerals, vitamins, dietary fibres, carbohydrates and proteins. So it has many potential application. It contains many bioactive compounds which are galactomannan, diosgenin, 4-hydroxyisoleucene, 3hydroxy-4,5-dimethyl-2(5H) furanone (stolone), etc. Fenugreek have an hypocholesterolemic, hepatoprotective effect, antioxidant potency, digestive stimulant action. It is an anticarcinogenic, antioxidant, antimicrobial agent, gastric stimulant and anti-anorexia agent. These physical properties were evaluated by medicinal and nutritional study. In this review, we will know about the nutritional, nutraceutical, antioxidant and medicinal properties of fenugreek.
\end{abstract}

Keywords: Fenugreek, bioactive compounds, medicinal and nutraceutical effects.

\section{INTRODUCTION}

Fenugreek is a good medicinal plant which comes under leguminous crops and its self-pollinating. It has been used as a medicinal plant since more than 4000 years in various parts of the world. It presence of pungent aromatic compounds in their seeds that gives colour, flavour and aroma to food "Buba.F et.al". It mostly found in India, North America, certain regions of Africa and in some parts of Australia. Mainly fenugreek herb is harvested in central Asia, Europe, Northern Africa, Northern America and parts of Australia and India having the largest producer in the world. It has wide therapeutic applications including carminative, aphrodisiac, lactation stimulant in women after child birth in traditional Chinese medicine, as well as Indian Ayruvedic medicines "Titran D et.al (2003)". They have many effects Eg: Anthelmintic, antinociceptive anticancer, anti-dicer, antibacterial, gastro and hepatoprotective, immunomodulatory etc "Acharya SN et.al (2007)".

The bioactive compounds of fenugreek include polyphenolic compounds, flavanoids, steroids, sapogenins, alkaloids and many volatile compounds of anethole and stolone. This plant is used as a supplement in maize and wheat flour for bread making in vemen and Persia. It is used for daily meal preparation. It helps in diabetes control and cardiovascular health issues "Tabasum Fatima Maqbool et.al". Trigonelline compound can be present seeds and it based for the manufacture of maple syrup and as an artificial flavour for vanilla, butterscoth etc. The several fenugreek composition was shown in table: 4

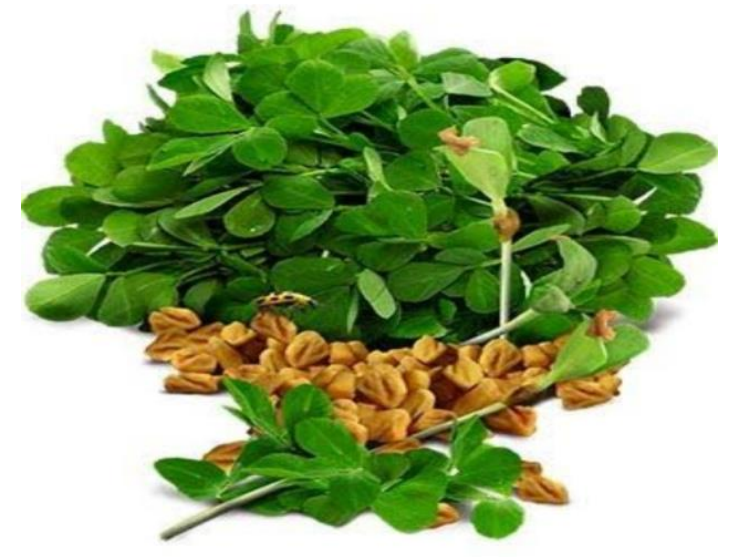

Table 1: Classification of Fenugreek

$\begin{array}{lll}\text { DOMAIN } & : & \text { EUKARYA } \\ \text { Kingdom } & : & \text { Plantae } \\ \text { Division } & : & \text { Magnoliphyta } \\ \text { Class } & : & \text { Magnoliopsida } \\ \text { Order } & : & \text { Fabales or Leguminales } \\ \text { Family } & : & \text { Fabaceae } \\ \text { Sub-family } & : & \text { Trifoliae } \\ \text { Genus } & : & \text { Trigonella } \\ \text { Sub-genus } & : & \text { Foenumgraecum } \\ \text { Species } & : & \text { Trigonella foenum-graecum }\end{array}$




\section{International Journal of Engineering Applied Sciences and Technology, 2019 \\ Vol. 4, Issue 7, ISSN No. 2455-2143, Pages 332-335 \\ Published Online November 2019 in IJEAST (http://www.ijeast.com)}

\section{AS A FORAGE CROP}

In the presence of fenugreek, the large amount of amino acids, proteins and vitamins has found a high forage value hence it is digestible in cattle. The incorporation of fenugreek in cattle dairy diet resulted in good content of fatty acid in milk and it shows an increases in polyunsaturated fatty acid "Huggins K et.al (1998)". It has the $4 \%$ reduction in blood cholesterol as compared to control "Basch et.al (2003)". Due to this reason, it has many health benefits in humans.

\section{AS A FOOD STABILIZER, ADHESIVE AND EMULSIFYING AGENT}

Only galactomannan presence in fenugreek seeds alone accounts for approximately $15-50 \%$ dry weight of seed which is a standard source of dietary fiber in plant which help in many disease combating symptoms "Shrivastava $\mathrm{R}$ et.al (2013)". It also enhances the bread quality of wheat flour when incorporated and also reported to increases the nutritional quality of bread "Mulidhar M et.al (2012)". Galactomannan acts as thickener in certain foods like soups and ice-creams "Khorshidian $\mathrm{N}$ et.al (2016)". In industries, they produces locust bean gum and guar gum which are used as an emulsifiers, thickeners and stabilizers.

\section{PHYSICAL PROPERTIES:}

In physical properties, fenugreek seeds were evaluated by measuring the length, thickness, width, seed mass are measured "Atluntas E et al. (2005)".

Table 2: Physical properties of fenugreek seeds

\begin{tabular}{|l|l|l|l|l|}
\hline $\begin{array}{l}1000 \\
\text { seed } \\
\text { Mass, } \mathrm{g}\end{array}$ & $\begin{array}{l}\text { Bulk } \\
\text { density, } \\
\mathrm{g} / \mathrm{ml}\end{array}$ & $\begin{array}{l}\text { Kernel } \\
\text { density, } \\
\mathrm{g} / \mathrm{ml}\end{array}$ & $\begin{array}{l}\text { Porosity, } \\
\%\end{array}$ & $\begin{array}{l}\text { Angle of } \\
\text { Response, }^{\circ}\end{array}$ \\
\hline $14,40 \mathrm{~g}$ & $6.51 \mathrm{~g}$ & $1.190 \mathrm{~g}$ & $42.51 \%$ & $13.53^{\circ}$ \\
\hline
\end{tabular}

\section{CHEMICAL PROPERTIES:}

The chemical properties of raw and germinated fenugreek seeds $(\% \mathrm{~d} / \mathrm{b})$ were analysed as moisture, fat, protein, ash content and carbohydrate content "Ms. Syed Ayesha Rasheed et.al".

Table 3: Chemical properties of fenugreek

\begin{tabular}{|l|l|l|l|l|l|}
\hline $\begin{array}{l}\text { Name of } \\
\text { sample }\end{array}$ & $\begin{array}{l}\text { Moistur } \\
\text { e }(\%)\end{array}$ & $\begin{array}{l}\text { Fat } \\
(\%\end{array}$ & $\begin{array}{l}\text { Protei } \\
\mathbf{n}\end{array}$ & $\begin{array}{l}\text { As } \\
\text { h }\end{array}$ & $\begin{array}{l}\text { Carbohydrat } \\
\text { e }(\%)\end{array}$ \\
& & ) & $(\%)$ & \\
\hline
\end{tabular}

\begin{tabular}{|l|l|l|l|l|l|}
\hline $\begin{array}{l}\text { Raw } \\
\text { fenugreek } \\
\text { Seeds }\end{array}$ & 11.21 & 7 & 23.30 & 3 & 55.49 \\
\hline $\begin{array}{l}\text { Germinate } \\
\text { d }\end{array}$ & 13.50 & 6.2 & 24.12 & 3.1 & 53 \\
fenugreek \\
seeds
\end{tabular}

Table 4: Chemical constituents of fenugreek:

\begin{tabular}{|c|c|}
\hline $\begin{array}{l}\text { Classes of } \\
\text { chemical } \\
\text { constituents }\end{array}$ & Chemical constituents \\
\hline Proteins & Globulin, Albumin and Lecithin \\
\hline Lipid fatty acids & $\begin{array}{l}\text { Linoleic acid, A-Linolenic, Oleic, } \\
\text { Stearic acids, Palmitic and Sterols: B- } \\
\text { Sitosterol, Campesterol, Cycloartenol, } \\
\text { Triacyl glycerides. }\end{array}$ \\
\hline Carbohydrates & Mucilage or gum: Galactomannan \\
\hline Saponins & $\begin{array}{l}\text { Fenugrin B, } \quad \text { Fenugreekine, } \\
\text { Trigofoenosides A-G, graecunins }\end{array}$ \\
\hline Steroidal Saponins & $\begin{array}{l}\text { Diosgenin, Yamogenin, Gitogenin, } \\
\text { Tigogenin, Neogitogenin, Smilagenin, } \\
\text { Sarsasapogenin. }\end{array}$ \\
\hline Flavanoids & $\begin{array}{l}\text { Apeginin, Luteolin, Vitexin, Isovitexin, } \\
\text { Irilone, Tricine, Calycosin, } \\
\text { Daidezin,Orientin. }\end{array}$ \\
\hline Alkaloids & $\begin{array}{l}\text { Trigonelline, Choline, Carpaine, } \\
\text { Gentianine. }\end{array}$ \\
\hline Fibers & $\begin{array}{l}\text { Gum, neutral detergent fiber lipids } \\
\text { triacylglycerols, phosphatidylcholine. }\end{array}$ \\
\hline Amino acids & $\begin{array}{l}\text { Isoleucine, Leucine, lysine, Arginine, } \\
\text { Histidine. }\end{array}$ \\
\hline
\end{tabular}




\section{International Journal of Engineering Applied Sciences and Technology, 2019 \\ Vol. 4, Issue 7, ISSN No. 2455-2143, Pages 332-335 \\ Published Online November 2019 in IJEAST (http://www.ijeast.com)}

\section{BIOACTIVE COMPOUNDS OF FENUGREEK}

\section{Steroid saponins:}

Fenugreek seeds does not contain free saponins but they occur as a complex glycosides. Sapogenins are derived from the glycone portion of the plant. They have the medicinal property to reduce the level of serum cholesterol "Sauvaire Y et.al".

\section{Alkaloids:}

In fenugreek seeds trigonelline is a methy betaine derivative of nicotinic acid is the major alkaloid. They can treat diabetes and central nervous system diseases. It shows an antibacterial, antiviral and memory improving activities "NIN report et.al".

\section{Galactomann:}

It is an compound of cell wall and it also an major polysaccharide found in fenugreek. It can reduce the plasma glucose level and also has anti-diabetic effect "Borida et.al".

\section{Volatile compounds:}

Stolone - furanone is the principle of volatile compound in fenugreek. Carbonyles and sesquiterpene is also an other volatile compounds. It shows an antimicrobial properties against bacteria, yeast and fungi "Mulidhar M et.al (2012)".

\section{4-Hydroxyisoleucine:}

It most commonly found in free amino acids in fenugreek seeds. It occurs in two isomeric forms. It has an anti-diabetic agent "Shalini Hooda et.al (2003)".

\section{MEDICINAL PROPERTIES}

Fenugreek plant contain many medicinal properties. They can be tried and experimented by using both humans and animals "Sowmya P et.al". They have been reported that the antidiabetic and blood lipid lowering effect "anuradha $\mathrm{CV}$ et.al (2001)". In the presence of nutritional compounds are mostly taken in diet. Fenugreek seeds helps to beneficial influence on digestion and also has the ability to modify food texture "Suileman Y et.al (1991)". Fenugreek contains saponins, hemicelluloses, mucilage, tannins and pectin compounds helps to decrease the level of low density lipoprotein cholesterol (LDL) in blood "Borida A et.al".

\section{CONCLUSION}

Present review focuses on nutritional and health benefits of fenugreek. The bioactive components of fenugreek giving it promising the nutritional and health beneficial properties. It can be used as therapeutic drug for curing many types of diseases as well as its extracted compounds can be used individually in drug designing and discovery. Major health beneficial properties of fenugreek are antioxidant, antifungal, antidiabetic, anticarcinogenic, hypoglycaemic activity and hypocholesterolemic activity. The consumption of fenugreek has safe and secure for humans and it may be implemented for health benefit as dietary component, through its rich full of fiber packaged and other bioactive components are present. Future research on this plant could lead to the medicine and pharmaceutical industries due to herbal nature and low side effects. So in scientific research areas fengrueek plays a major role.

\section{ACKNOWLEDGEMENT}

The author express their gratitude towards the host institution Dr.N.G.P Arts and Science College, Management, Principal, Deans, Head of the Department, Guide and other all staffs of the Department of Biotechnology for rendering all the facilities and support. Communication no: Dr NGPASC 2019-20 BS020.

\section{REFERENCE}

[1] Altuntas E, Ozgoz E, Taser O.F, 2005 “' some physical properties of fenugreek (Trigonella foenum graceum) seeds“. Journal of food engineering. 71(2005), pg 37-43.

[2] Acharya SN, Basu SK, Thomas JE 2007. Medicinal properties of fenugreek ( Trigonella foenum graecum): a review of the evidence based information. Av Med Plant Res ; pg 81-122.

[3] Abdo MS, Al-kafawi AA1968. Experimental studies on the effect of Trigonella foenum-graecum. Planta Med. ;17: pg14-8.

[4] Anuradha, C.V., Ravikumar, P., 2001. Restorationon tissue antioxidants by fenugreek seeds ( $T$. foenum- graecum) in alloxan-diabetic rats. Ind. J. Physiol. Pharmacol. 45,pg 408-420.

[5] Blank, I. (1996). The flavour principle of fenugreek. Nestle research center. $211^{\text {th }}$ ACS Symposium. New Orleans, pg2428.

[6] Buba F., Ngura U and Abdulrahman A.A, Studies on the physiochemical properties of fenugreek (Trigonella foenumgraecum).

[7] Basch E, Ulbricht C, Kuo G, Szapary P, Smith M. Therapeutic applications of fenugreek. Altern Med. Rev. 2003;8(1): pg 20-27.

[8] Dixit P, Ghaskadbi S, Mohan H, Devasagayam TPA (2005). Antioxidant properties of germinated fenugreek seeds. Phytother Res. 2005; 19:pg 977-983.

[9] Ebubekir Atluntas, Engin Ozgoz, O. Faruk Taser . Some physical properties of fenugreek (Trigonella foenum graceum L.) seeds, Journal of food engineering 71, pg37-43.

[10] Flammang Am, Cifone MA, Erexson GL, Stankowski LF 2004., Jr Genotoxicity testing of fenugreek extract. Food chem. Toxicol. ;42: pg1769-75.

[11] Food reference, 2004. Food history, herbs: fenugreek, food reference website, www.foodreference.com.

[12] Fazli FRY, Hardman R 1971. Isolation and characterization of steroids and other constituents from 


\section{International Journal of Engineering Applied Sciences and Technology, 2019 \\ Vol. 4, Issue 7, ISSN No. 2455-2143, Pages 332-335 \\ Published Online November 2019 in IJEAST (http://www.ijeast.com)}

(Trigonella foenum graceum L.) Phytochemistry ; 10: pg24972503.

[13] Hannana, J.M.A., Rokeya, B., Faruque,O., Nahar, N., Mosihuzzaman, M., Azad Khana, A.K., Alia, L 2003.;Effect of soluble dietary fibre fraction of Trigonella foenum-graecum on glycemic, insulinemic, lipidemic and platelet aggregation status of Type 2 diabetic model rats;; Journal of Ethnopharmacology 88 pg73-77.

[14] Hooda S and Jood S, 2002 " Effect of soaking and germination on nutrient and antinutrient contents of fenugreek (Trigonella foenum graceum L.) “. Journal of food Biochemistry, 27, pg165-176.

[15] Huggins k. Fenugreek 1998; One remedy for low milk production. Rental Roundup, ; 15(1):pg 16-7.

[16] Kaviarasan S, Anuradha C 2007. Fenugreek (Trigonella foenum graceum) seed polyphenols protect liver from alcohol toxicity: a role on hepatic detoxification system and apoptosis. Pharmazie, ; 62(4):pg299-304.

[17] Khorshidian N, Mojtaba YA, Masoumeh A, Mirzaie AA, Amir MM 2016. Fenugreek: potential applications as a functional food and nutraceutical. Nutrition and food science research. ; 3(1); pg5-16.

[18] Meghwal M, Goswami TK.2012 A review on the functional properties, Nutritional content, Medicinal utilization and potential application of fenugreek. J Food process technol, ; 3(9).

[19] Mulidhar M and Goswami T.K, 2012 “" A review on the functional properties, nutritional content, medicinal utilization and potential application of fenugreek" . Journal food process technology, 3(9), pg 1-10.

[20] NIN Report (1987). Use of fenugreek seed powder in the management of non-insulin dependent diabetes mellitus. NIN, ICMR, Hydrabad, India.

[21] Neeraja A, Rajyalakshmi P 1996. Hypoglycemic effect of processed fenugreek seeds in humans. J Food Sci Technol ;33pg:427-430.

[22] Pandian RS, Anuradha CV, Viswanathan P 2002. Gastroprotective effect of fenugreek seeds (Trigonella foenum graecum) on experimental gastric ulcer in rats. $\mathbf{J}$ Ethnopharmacol ; 81;pg393-397.

[23] Puri D, Prabhu KM, Murthy PS 2002. Mechanism of action of a hypoglycaemic principle isolated from fenugreek seeds Indian J. Physiol. Pharmacol; 46:pg457-62.

[24] Raju J, Bird R 2006. Alleviation of hepatic steatosis accompanied by modulation of plasma and liver TNF- $\alpha$ levels by Trigonella foenum graceum (Fenugreek) seeds in Zucker obese(fa/fa) rats. Int J Obesity. ; 30(8): pg1298-307.

[25] Raghuram TC, Sharma RD, Sivakumar B, Sahay BK. 1994 Effect of fenugreek seeds on intravenous glucose disposition in non-insulin dependent diabetic patients. Phytother Res.;8:pg83-86.

[26] Sowmya P, Rajyalakshmi P 1999. Hypocholesterolemic effect of germinated fenugreek seeds in human subjects. Plant Foods Hum Nutr ;53:pg 359-365.
[27]Singhal PC, Gupta RK, Joshi LD 1982. Hypocholesterolmic effect of seeds. Current science. ; 51:pg 136-137.

[28] Ms. Syed Ayesha Rasheed, Physico- chemical properties of fenugreek (Trigonella foenum-graecum).

[29] Shrivastava R,Meena M,Meena V,Kosta S,Ravindra K 2013. A prospective study to see the effect of fenugreek seed powder as hypoglycemic agent on typeII diabetes mellitus.International Journal of Bioassays.

[30] Syeda BB, Muhammad IB, Shahabuddin M 2008. Antioxidant activity from the extract of fenugreek seeds. Pak. J. Anal. Environ. Chem; 9(2):pg 78-83.

[31] Shalini Hooda and Sudesh Jood 2003 Effect of soaking and germination on nutrient and antinutrient contents of fenugreek (Trigonella foenum graceum L.) Journal of Food Biochemistry 27, pg165-176.

[32] Shakuntala,S., Naik, J. P., Jeyarani, T., Naidu, M. M. And Shrinivas, P. 2001. Characterization of germinated fenugreek (Trigonella foenum graceum) seed fractions, International journal of food science and technology, 46, pg 2337-2343.

[33] Suileman AME, Ali AO, Hemavathy J 2008. Lipid content and fatty acid composition of fenugreek (Trigonella foenum graceum L.) seeds grow in Sudan. Int $\mathrm{j}$ food Scitech ; 43:380-382.

[34] Sauvaire Y, Ribes G, Baccou J, et al 1991. Implication of steroid saponins and sapogenins in thehypocholesterolemic effect of fenugreek. Lipids ;26:191-197.

[35] Tabasum Fatima Maqbool and Syed Zameer Hussain, Potential health benefits of fenugreek.

[36] Titran D 2003 The use of fenugreek for breast feeding women Complement The Nurs Midwifery; 9:155-156. 